\title{
A REVIEW OF GLOBAL LAND COVER MAPS IN TERMS OF THEIR POTENTIAL USE FOR HABITAT SUITABILITY MODELLING
}

\author{
ANASTASIA LINYUCHEVA ${ }^{1, *}$ and PAVEL KINDLMANN ${ }^{1,2}$ \\ ${ }^{1}$ Global Change Research Institute, Czech Academy of Science, Bělidla 986/4a, 60300 Brno, Czech Republic \\ 2 Institute for Environmental Studies, Faculty of Science, Charles University, Benátská 2, 12801 Prague 2, Czech Republic \\ * Corresponding author: anastasia.linyucheva@seznam.cz
}

\section{ABSTRACT}

Recently, there has been a significant increase in number of land cover maps available to researchers and they are now more commonly used. The broad variety requires some system for determining the differences between maps and for estimating their applicability for specific research purposes. We focused on comparing land cover maps from the point of view of how the land cover categories used characterize potentially suitable habitats for species. This comparison includes only freely available global land cover projects with resolutions from $1 \mathrm{~km}$ to $10 \mathrm{~m}$. The criteria chosen were temporal and spatial resolution, number of classes and map precision. To demonstrate the differences, two areas of different sizes were always chosen. Our results reveal that maps can significantly vary in their estimates of different types of land cover, even at the same spatial resolution. Results also revealed that one type of vegetation in this area is poorly recorded in all land cover maps. Copernicus CGLS-LC100 and ESA CCI-LC maps appear to be the most suitable for evaluating potentially suitable habitats.

Keywords: comparison; Copernicus; ESA; FAO; habitat connectivity; habitat suitability

\section{Introduction}

The number of land cover maps and their use by researchers is greatly increasing. Earth observation satellites, such as Sentinel missions, Landsat missions, Terra and others provide data for these maps. Researchers can gain access to satellite imagery data with various levels of processing, such as an image of the Earth's surface with several bands, or an already processed map that is ready for analysis. Acquiring unprocessed satellite images could be a better option for a relatively small area, especially if it consists of a few images. Land cover maps can be created from satellite images in free open-source programs (Manton et al. 2005; Ndegwa Mundia and Murayama 2009; Barik et al.2021). Precision of such maps depends not only on the quality of satellite imagery (Manton et al. 2005), but also on the classification approach (Li et al. 2017) and on type of data used (Novillo et al. 2018). However, for a global scale study, creating land cover maps from individual satellite images is extremely time consuming and this process will often exceed storage memory and processing capacities of a personal computer. Proper measuring of the precision of the final world map is an impossible task for an ordinary researcher. An average researcher, who is not specialized in processing remote sensing data, would be unable to correctly measure the precision of the final world map. Therefore, only land cover maps that do not require further processing were included in this comparative study. Some of these maps were created using data from several satellite sensors and replicating this method on a personal computer is unrealistic.

Land cover maps can be used in various fields of study: habitat connectivity (Ciudad et al. 2021), effect of changes in land use (Barik et al. 2021), conservation planning
(Falcucci et al. 2007), climate change (McMenamin et al. 2008) and forest monitoring (Rawat and Kumar 2015). Here we consider using land cover maps for estimating land cover of habitats that are potentially suitable for species on a global scale. For example, for epiphytic orchids, tropical forest is one of its suitable habitats. Evaluation of habitat suitability should be based on multiple sources of information (Manton et al. 2005; Hirzel and le Lay 2008). Nevertheless, land cover maps can be used to estimate, e.g., habitat connectivity (Cisneros-Araujo et al. 2021). Here we concentrate on usefulness of such maps for estimating site connectivity (e.g. that of an island or protected area) and habitat suitability for a species.

For the purpose of this study, maps should have certain characteristics. In order to correctly determine potentially suitable habitat, the map should temporally match that at the time the occurrence records were collected. It is worth considering using a series of land cover maps to determine changes over time, such as population dynamics (Ndegwa Mundia and Murayama 2009), the effect of changes in land cover on a species' habitat (Breininger et al. 2006), etc. Obtaining a time series of maps for a single project might minimize the bias in the resulting estimates of potentially suitable habitat, particularly if the maps were developed using the same algorithms and data from the same satellites. The map should have an appropriate spatial resolution. Choosing the appropriate spatial resolution is crucial for evaluating the pattern of potentially suitable habitat, since the final estimate of the extent of suitable habitat is highly dependent on the resolution of the land cover map (Rondinini et al. 2011; Ciudad et al. 2021). This decision is primarily based on the ecology of the species studied and purpose of the research. Overall, a too coarse resolution can omit habitat 
fragmentation, resulting in an inaccurate estimate of the extent of suitable habitat. Displaying interactive maps in online map viewer, for example on the FAO GeoNetwork, should be treated with caution, as it tends to inflate the real resolution of the map. Number of classes needed for evaluating suitable habitat also depends on the aim of the study. A map with fewer classes, but higher resolution, would better reflect the average distribution of these classes than a coarser map with the same classification. However, for types of vegetation (forests, shrubs, etc.) it is important to provide multiple subcategories, since such categories have critical details for evaluating habitat suitability. E.g., category "Mosaic tree and shrub (> 50\%) / herbaceous cover (<50\%)" in CCI-LC map (ESA 2017) provides more information than "Shrub Covered Areas" in GLC-SHARE map (Latham et al. 2014).

\section{Materials and Methods}

Maps were obtained from a variety of sources, the NASA Earthdata Search, ArcGIS, Zenodo and FAO GeoNetwork. 254 maps were found using NASA Earthdata Search using the keywords "Land use/Land cover" and "Global." The majority were individual satellite images or specific small areas, which often included other categories of maps besides land cover maps (normalized difference vegetation index (NDVI), snow-free albedo, etc.). The names of projects and platforms (satellites or sensors) used in the development of global cover maps were the main results of this search. The agencies that provide final land cover maps, such as ESA, Copernicus and FAO, were discovered after searching individual projects and sensor names. GLOBCOVER and GLC-SHARE maps were found in the FAO GeoNetwork. The ArcGIS online Map Viewer was used to visually inspect some of the projects (MODIS, ESA). Maps GLC_FCS30, FROM-GLC10 were downloaded from Zenodo service. ESA and Copernicus maps were obtained directly from the respective agencies.
The final selection of land cover maps is listed in Table 1. All the maps listed are free to download and links to websites are given at the end of this paper. The maps were selected using the criteria outlined below. Two different sized areas were chosen to illustrate the variations in detail captured by each map. The large area is $60 \times 115 \mathrm{~km}$ in size. It includes part of Croatia and nearby small islands: Čiovo $\left(28.8 \mathrm{~km}^{2}\right)$, Drvenik veli $\left(12.07 \mathrm{~km}^{2}\right)$, Drvenik mali $\left(3.43 \mathrm{~km}^{2}\right)$, Šolta $\left(58.98 \mathrm{~km}^{2}\right)$, Brač $\left(396 \mathrm{~km}^{2}\right)$, Hvar $\left(297.4 \mathrm{~km}^{2}\right)$, Paklinski islands $\left(7.165 \mathrm{~km}^{2}\right)$, Šćedro $\left(8.36 \mathrm{~km}^{2}\right)$. Small area is approximately $4 \times 4 \mathrm{~km}$ in size. It includes a part of Čiovo island, which has a mosaic of forests, shrubs and open areas, and quite a large amount of urban areas along the coast and there does not seem to be any crops, only orchards, but definitely open herbaceous vegetation. Such a small area was chosen to demonstrate the accuracy of each map. For the smaller area, map classification was compared with Google Earth satellite imagery (Gorelick et al. 2017).

The following criteria for selecting maps were determined based on their potential use in evaluating habitat connectivity or habitat suitability:

\section{Matching time periods}

Some projects include land cover maps for earlier periods (ESA CCI-LC map is available from the year 1992), while others are for a specific short period of time (ESA GLOBCOVER map). There are projects that predict historical land use changes, such as ISLSCP II data collection (International Satellite Land-Surface Climatology Project, Initiative II), which includes 50 global time series data sets from 1986 to 1995 and describes historical changes in land use over a period of 300 years (1700-1990) (Goldewijk et al. 2007). Or, for example, a project from the United States Geological Survey (USGS), which is only for the years 1992-1993, but contains more data for this period of time. It provides not only a map of land cover, but also a global ecosystems map, simple biosphere model, biosphere-atmosphere transfer scheme, and vegeta-

Table 1 Final map selection.

\begin{tabular}{|c|c|c|c|c|c|c|}
\hline Data provided by & $\begin{array}{l}\text { Map } \\
\text { name }\end{array}$ & Resolution & $\begin{array}{l}\text { Number } \\
\text { of classes }\end{array}$ & $\begin{array}{l}\text { Approximate } \\
\text { file size }\end{array}$ & $\begin{array}{l}\text { Overall mapping } \\
\text { accuracy }\end{array}$ & $\begin{array}{l}\text { Temporal } \\
\text { coverage }\end{array}$ \\
\hline Copernicus & CGLS-LC100 & $100 \mathrm{~m}$ & 23 & $53 \mathrm{~GB}$ & $\begin{array}{l}80.6 \% \text { in } 2015 \\
80.3 \% \text { in } 2019\end{array}$ & 2015-2019 \\
\hline $\begin{array}{l}\text { Food and Agriculture Organization } \\
\text { of the United Nations (FAO) }\end{array}$ & GLC-SHARE & $1000 \mathrm{~m}$ & 11 & $35.2 \mathrm{MB}$ & $80.2 \%$ & 1998-2012 \\
\hline European Space Agency (ESA) & CCI-LC & $300 \mathrm{~m}$ & 37 & $\begin{array}{l}258 \mathrm{MB} \\
/ 2.3 \mathrm{~GB}\end{array}$ & $75.4 \%$ & $\begin{array}{c}1992 \text { - present with } \\
\text { one year delay }\end{array}$ \\
\hline European Space Agency (ESA) & GLOBCOVER & $300 \mathrm{~m}$ & 22 & $374 \mathrm{MB}$ & $67.10 \%$ & $\begin{array}{l}12.2004-06.2006 \\
01.2009-12.2009\end{array}$ \\
\hline Liangyun et al. 2020 (open access) & GLC_FCS30 & $30 \mathrm{~m}$ & $9 / 16 / 24$ & $21 \mathrm{~GB}$ & $\begin{array}{c}82.5 \% / 71.4 \% \\
\quad / 68.7 \% \\
\end{array}$ & 2015,2020 \\
\hline Gong et al. 2019 (open access) & $\begin{array}{l}\text { FROM- } \\
\text { GLC10 }\end{array}$ & $10 \mathrm{~m}$ & $\begin{array}{l}27(2015) \\
11(2017)\end{array}$ & unknown & $72.76 \%$ & 2015,2017 \\
\hline
\end{tabular}


tion lifeform map. Monthly NDVI composites, however, are only available on the continent-scale map (GLCC).

\section{Temporal resolution}

The majority of the final products have the same temporal resolution (one year), which may be insufficient for analyses requiring a finer temporal resolution (Ciudad et al. 2021). Unfortunately, there is no global land cover map with a lower temporal resolution. Indexes, characterizing vegetation, such as normalized difference water index or normalized difference vegetation index are produced monthly and can be used as substitution for a land cover map (Teng et al. 2021). If a land cover map is needed for a particular time period, for a smaller area it can be created using satellite imagery (Pennington et al. 2008; Li et al. 2017).

\section{Spatial resolution}

Maps with resolutions greater than $1 \mathrm{~km}$ were excluded from the comparison due to the loss of landscape features (islands, water bodies, etc.) at such resolutions.
Highest global land cover map resolution that is currently available is $30 \mathrm{~m}$ (considering only publicly available projects from major agencies, for which this precision was thoroughly evaluated). There are companies that provide higher-resolution maps, for example, $10 \mathrm{~m}$ BaseVue maps from 2005 to the present time (MAXAR 2021). However, these maps have to be purchased and are provided on request, for a user-defined area. Alternatively, such maps can be obtained from open projects, such as FROM-GLC10 with a resolution of $10 \mathrm{~m}$ (Gong et al. 2019).

\section{File size}

Since this is primarily determined by map resolution, a direct comparison would be unreasonable. Even so, due to the difference in raster compression methods, the size of the final product will vary between maps with a similar resolution. Distributors provide well-compressed maps, but it should be mentioned that file size can drastically change after re-saving, for example, after exporting categories into separate files. This may present a problem, es-

Table 2 Land cover classes included on CGLS-LC100 map, taken from Buchhorn et al. (2020). Corresponding land cover map is shown in Fig. 1.

\begin{tabular}{|c|c|}
\hline Land cover class & Definition \\
\hline $\begin{array}{l}\text { Closed forest, evergreen } \\
\text { needles }\end{array}$ & Tree canopy $>70 \%$, almost all trees with needles remain green all year. Canopy is never without green foliage. \\
\hline $\begin{array}{l}\text { Closed forest, evergreen, } \\
\text { broad leaf }\end{array}$ & $\begin{array}{l}\text { Tree canopy }>70 \% \text {, almost all trees are broadleaved and remain green all year. Canopy is never without green } \\
\text { foliage. }\end{array}$ \\
\hline $\begin{array}{l}\text { Closed forest, deciduous } \\
\text { needles }\end{array}$ & Tree canopy $>70 \%$, almost all trees bear needles and are deciduous. \\
\hline $\begin{array}{l}\text { Closed forest, deciduous } \\
\text { broad leaf }\end{array}$ & Tree canopy $>70 \%$, almost all trees are broadleaved and deciduous. \\
\hline Open forest, evergreen needles & $\begin{array}{l}\text { Top layer: trees } 15-70 \% \text { and second layer: mixed of shrubs and grassland, almost all the trees bear needles } \\
\text { and are evergreen. Canopy is never without green foliage. }\end{array}$ \\
\hline $\begin{array}{l}\text { Open forest, evergreen broad } \\
\text { leaf }\end{array}$ & $\begin{array}{l}\text { Top layer: trees } 15-70 \% \text { and second layer: mixed of shrubs and grassland, almost all the trees are broadleaved } \\
\text { and evergreen. Canopy is never without green foliage. }\end{array}$ \\
\hline Open forest, deciduous needles & $\begin{array}{l}\text { Top layer: trees } 15-70 \% \text { and second layer: mixed of shrubs and grassland, all the trees bear needles and are } \\
\text { deciduous. }\end{array}$ \\
\hline $\begin{array}{l}\text { Open forest, deciduous broad } \\
\text { leaf }\end{array}$ & $\begin{array}{l}\text { Top layer: trees } 15-70 \% \text { and second layer: mixed of shrubs and grassland, all the trees are broadleaved and } \\
\text { deciduous. }\end{array}$ \\
\hline Shrubs & $\begin{array}{l}\text { These are woody perennial plants with persistent woody stems and no main stem and are less than } 5 \mathrm{~m} \text { tall } \\
\text { the foliage of which can be either evergreen or deciduous }\end{array}$ \\
\hline $\begin{array}{l}\text { Herbaceous } \\
\text { vegetation }\end{array}$ & $\begin{array}{l}\text { Plants without persistent stem or shoots above ground and lacking definite firm structure. Tree and shrub } \\
\text { cover is less than } 10 \% .\end{array}$ \\
\hline $\begin{array}{l}\text { Cultivated and managed vege- } \\
\text { tation/agriculture (cropland) }\end{array}$ & $\begin{array}{l}\text { Land covered with temporary crops followed by harvest and a bare soil (e.g., single and multiple cropping sys- } \\
\text { tems). Note that perennial woody crops will be classified as the appropriate type of forest or shrub land cover. }\end{array}$ \\
\hline Urban / built up & Land covered by buildings and other man-made structures. \\
\hline Bare / sparse vegetation & Lands with exposed soil, sand, or rocks with never more than $10 \%$ covered with vegetation. \\
\hline Snow and ice & Lands under snow or ice throughout the year. \\
\hline Permanent water bodies & Lakes, reservoirs, and rivers. Can be either fresh or salt-water. \\
\hline \multicolumn{2}{|l|}{ Temporary water bodies } \\
\hline Herbaceous wetland & $\begin{array}{l}\text { Lands with a permanent mixture of water and herbaceous or woody vegetation. The vegetation can be } \\
\text { present in either salt, brackish, or fresh water. }\end{array}$ \\
\hline Open sea & Oceans, seas. Can be either fresh or salt-water bodies. \\
\hline
\end{tabular}




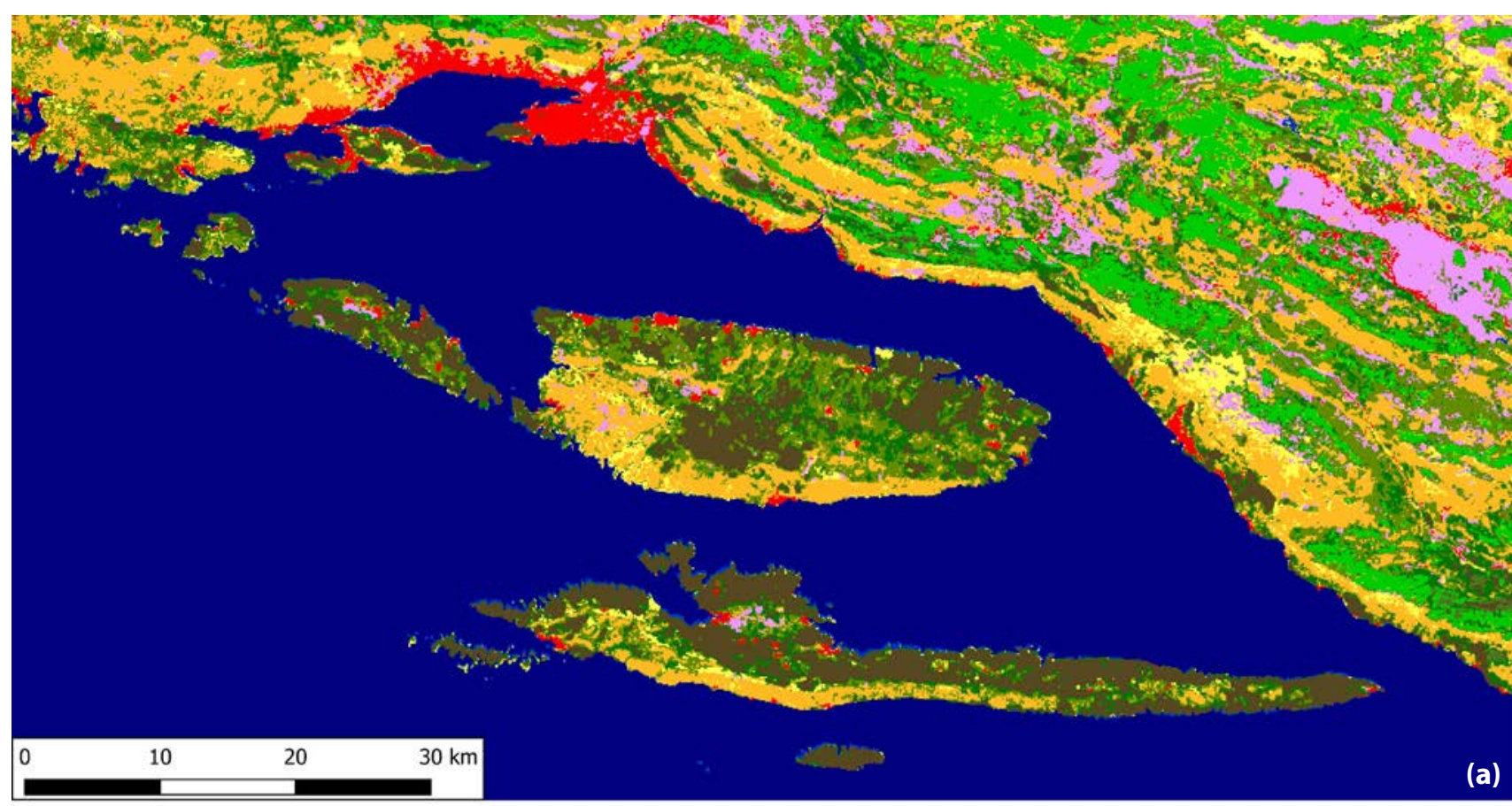

O
Shrubs
Herbaceous vegetation
Cultivated and managed vegetation/agriculture (cropland)
Urban / built up
Bare / sparse vegetation
Snow and Ice

Permanent water bodies

Herbaceous wetland

Moss and lichen

Closed forest, evergreen needle leaf

Closed forest, deciduous broad leaf

Closed forest, mixed

Closed forest, unknown
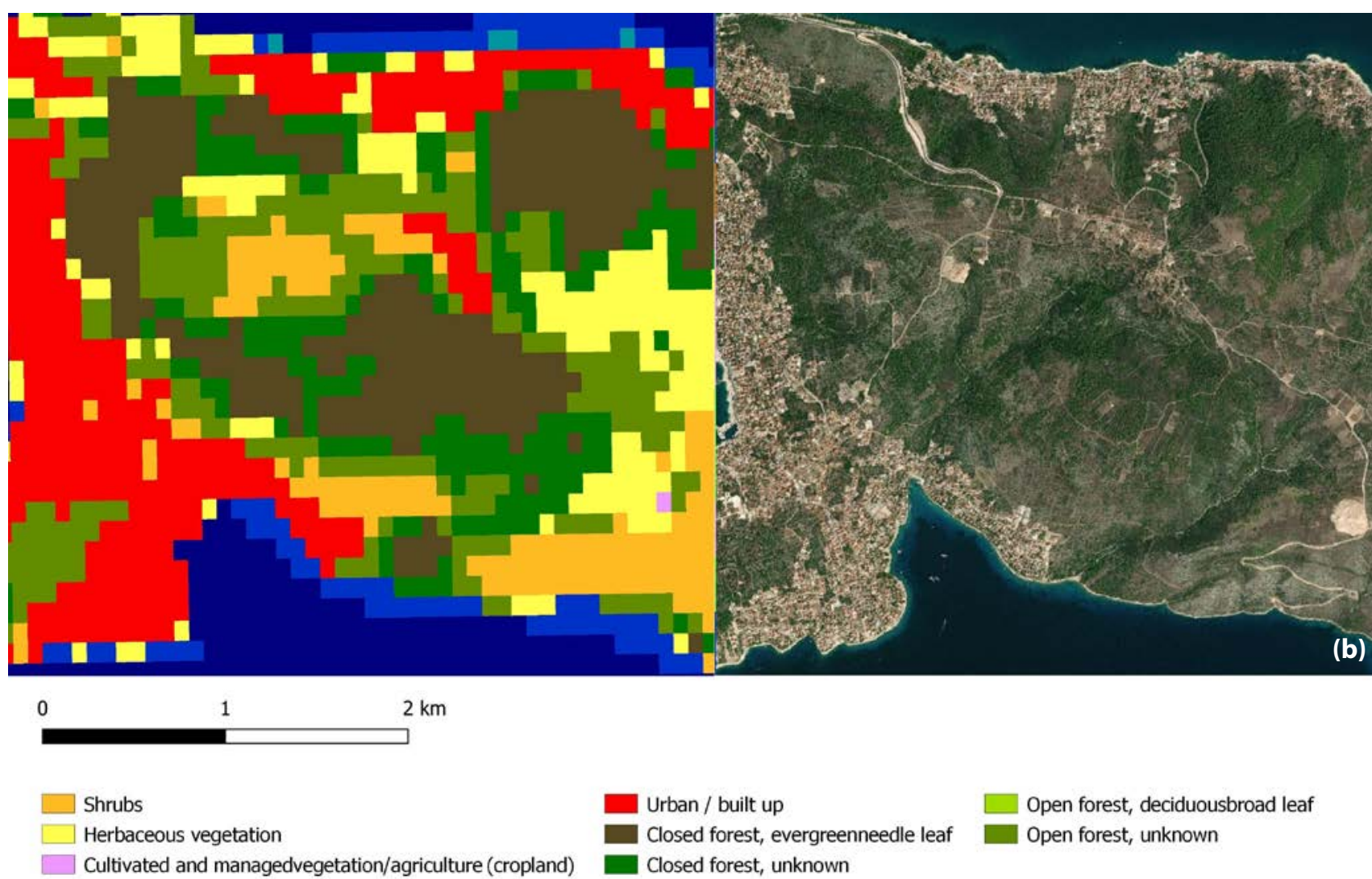

$\square$ Open forest, deciduousbroad leaf
Open forest, unknown

$\square$ Herbaceous vegetation

Closed forest, unknown

Fig. 1 Land cover map CGLS-LC100, (a) less detailed, legend includes all map classes; (b) more detailed, only the map classes present in the area are shown. 
pecially with maps with high spatial resolution and large compressed file sizes.

\section{Number of classes}

Some projects provide comparison of maps classification system with the Land Cover Classification System (LCCS). FAO created this method to provide a standardized structure for land cover classification and mapping. As a result, such projects are easier to compare.

\section{Map precision}

Due to the global scale of the data, the most reliable information on the precision of the final map can be obtained from the map's provider. The precision of a map may vary depending on the number of classes (for example, in the GLC FCS30 map), so the accuracy of same map depends on the number of classes used. Furthermore, the precision of a project's estimate of a specific land cover category can vary; this information is usually given in validation reports.

\section{Results}

\section{Copernicus global land service: land cover $100 \mathrm{~m}$ (Buchhorn et al. 2020)}

This project provides a comparison of map land cover classes with definition from LCCS classification system (Table 2). In addition to a map with 18 land cover classes, Copernicus provides layers that describe probability and quality of classification for each pixel. This map is also accompanied by cover layers, which define the percentage of pixels covered by a particular class pixel (forest, herbaceous vegetation, shrub, and bare soil) (Buchhorn et al. 2021).

Fig. 1a shows that the map not only depicts a high overall diversity of different types of land cover, but also a diversity on small islands and even the smallest island. Fig. $1 \mathrm{~b}$ gives a clear indication of the level of detail recorded. There are clear similarities in the detail in satellite imagery and a map characterization of land cover, even the shapes of urban areas are accurate. The only inaccu-

Table 3 CCI-LC map categories, adapted from ESA (2017). Corresponding land cover map is shown in Fig. 2.

\begin{tabular}{|c|c|}
\hline Global scale class & Regional scale class \\
\hline \multirow{2}{*}{ Cropland, rainfed } & Cropland, rainfed, herbaceous cover \\
\hline & Cropland, rainfed, tree or shrub cover \\
\hline \multicolumn{2}{|l|}{ Cropland, irrigated or post-flooding } \\
\hline \multicolumn{2}{|c|}{ Mosaic cropland (> 50\%) / natural vegetation (tree, shrub, herbaceous cover) $(<50 \%)$} \\
\hline \multicolumn{2}{|c|}{ Mosaic natural vegetation (tree, shrub, herbaceous cover) (> 50\%) / cropland $(<50 \%)$} \\
\hline \multicolumn{2}{|l|}{ Tree cover, broadleaved, evergreen, closed to open (> 15\%) } \\
\hline \multirow{2}{*}{ Tree cover, broadleaved, deciduous, closed to open (> 15\%) } & Tree cover, broadleaved, deciduous, closed (> 40\%) \\
\hline & Tree cover, broadleaved, deciduous, open (15-40\%) \\
\hline \multirow{2}{*}{ Tree cover, coniferous, evergreen, closed to open (> 15\%) } & Tree cover, coniferous, evergreen, closed (> 40\%) \\
\hline & Tree cover, coniferous, evergreen, open (15-40\%) \\
\hline \multirow{2}{*}{ Tree cover, coniferous, deciduous, closed to open (> 15\%) } & Tree cover, coniferous, deciduous, closed (> 40\%) \\
\hline & Tree cover, coniferous, deciduous, open (15-40\%) \\
\hline \multicolumn{2}{|l|}{ Tree cover, mixed leaf type (broadleaved and coniferous) } \\
\hline \multicolumn{2}{|l|}{ Mosaic tree and shrub (> 50\%) / herbaceous cover (<50\%) } \\
\hline \multicolumn{2}{|l|}{ Mosaic herbaceous cover (> 50\%) / tree and shrub (<50\%) } \\
\hline \multirow{2}{*}{ Shrubland } & Evergreen shrubland \\
\hline & Deciduous shrubland \\
\hline \multicolumn{2}{|l|}{ Grassland } \\
\hline \multicolumn{2}{|l|}{ Lichens and mosses } \\
\hline \multirow{3}{*}{ Sparse vegetation (tree, shrub, herbaceous cover) $(<15 \%)$} & Sparse tree cover $(<15 \%)$ \\
\hline & Sparse shrub cover $(<15 \%)$ \\
\hline & Sparse herbaceous cover $(<15 \%)$ \\
\hline \multicolumn{2}{|l|}{ Tree cover, flooded, fresh or brackish water } \\
\hline \multicolumn{2}{|l|}{ Tree cover, flooded, saline water } \\
\hline \multicolumn{2}{|l|}{ Shrub or herbaceous cover, flooded, fresh/saline/brackish water } \\
\hline \multicolumn{2}{|l|}{ Urban areas } \\
\hline \multirow{2}{*}{ Bare areas } & Consolidated bare areas \\
\hline & Unconsolidated bare areas \\
\hline \multicolumn{2}{|l|}{ Water bodies } \\
\hline Permanent snow and ice & \\
\hline
\end{tabular}



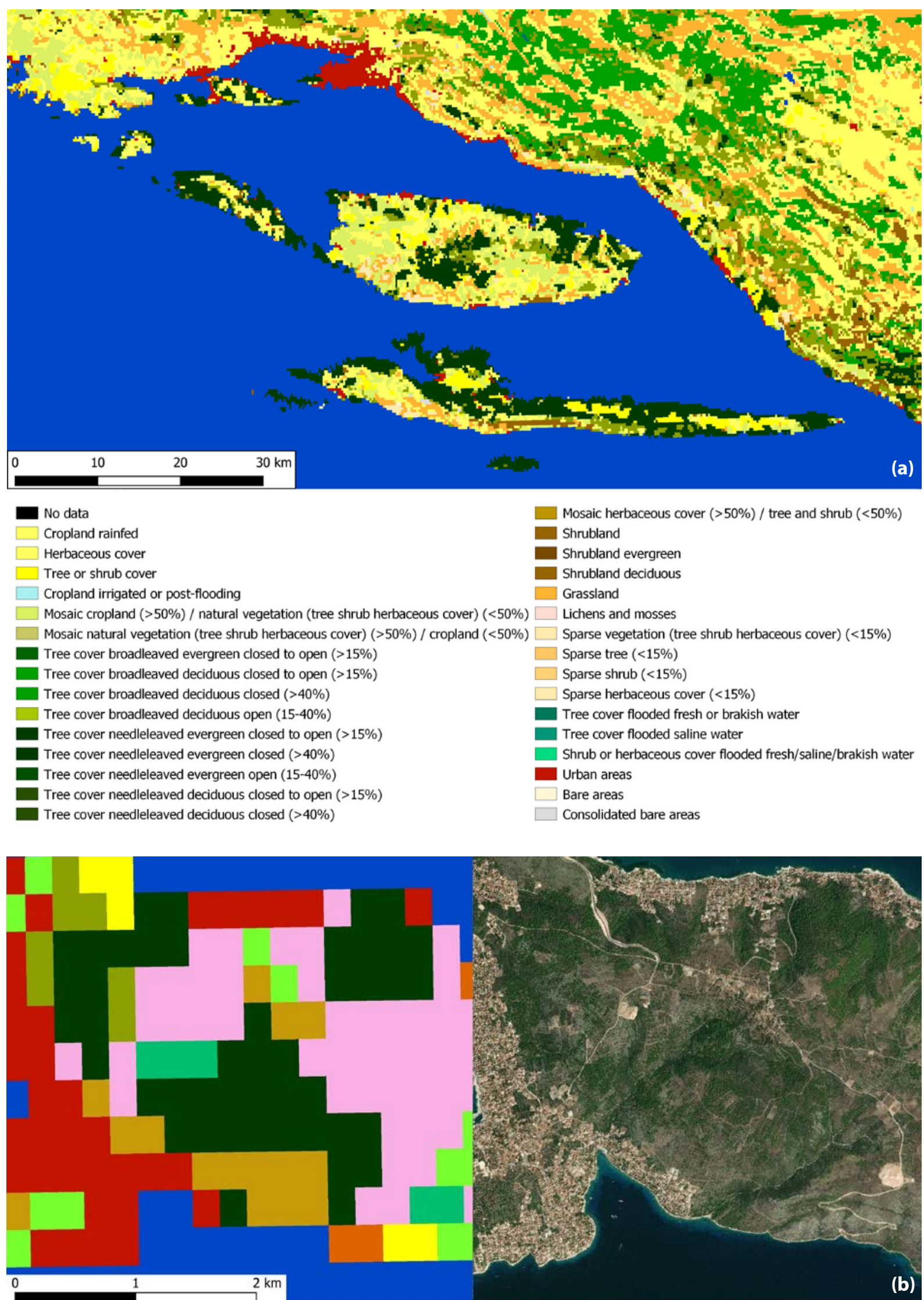
No data
Mosaic cropland (>50\%) / natural vegetation (tree shrub herbaceous cover) $(<50 \%)$
Grassland
$\square$ Cropland rainfed
Tree cover needleleaved evergreen closed to open $(>15 \%)$
Urban areas
$\square$ Herbaceous cover
Mosaic tree and shrub ( $>50 \%)$ / herbaceous cover $(<50 \%)$
Water bodies

$\square$ Tree or shrub cover $\square$ Shrubland

Fig. 2 Land cover map CCI-LC, (a) less detailed, legend includes all map classes; (b) more detailed, only map classes present in the area are shown. 
racy is that bare soil is categorized as cropland (one pink pixel bottom right). However, due to the small size of this patch, this misclassification is negligible, as it indicates there is a difference in the landscape.

\section{European Space Agency: Climate Change Initiative Land Cover map (CCI-LC) (ESA 2017)}

CCI-LC map categories are compatible with the LCCS coding. This map has two scales of categories (Table 3 ), in some areas, where certain types cannot be defined, global scale classes are substituted for regional scale classes.

CCI-LC correctly indicates the uneven distribution of different types of land cover, as shown in Fig. 2a, and it also includes the smallest islands. Visual estimates of overall diversity is difficult due to the similar colouration of categories (in Fig. 2a categories have the colours in ESA). This is not a problem if the map has already been downloaded. The disadvantage is that due to the higher spatial resolution, the majority of online map viewers will display this map in a very misleading manner (the map can be "upscaled" to a higher spatial resolution for a faster display). It is impossible to determine whether the area of interest is classified on a regional or global scale (all cropland and needle leaved forest classes are indistinguishable in terms of colour). In Fig. 2b, similar colours were changed. Fig. $2 \mathrm{~b}$ reveals that the map provides significantly less detail than Copernicus, but overall it is similar. Orchards were identified as rain fed croplands, which are categorized as cropland in this map.

\section{Food and agriculture organization of the United Nations: Global land cover SHARE (GLC-SHARE) (Latham et al. 2014)}

This project's map has only 11 classes, which are not compatible with the LCCS classification system, but in-

Table 4 Map categories with descriptions, taken from Latham et al. 2014.

\begin{tabular}{|c|c|}
\hline Land Cover & Description \\
\hline Artificial Surfaces & $\begin{array}{l}\text { This category includes any type of area with a predominantly artificial surface. Any urban or related feature is included, } \\
\text { for example urban parks (parks, parkland, sport facilities). It also includes industrial areas, waste dumps and extraction } \\
\text { sites. }\end{array}$ \\
\hline \multirow[t]{3}{*}{ Cropland } & $\begin{array}{l}\text { Herbaceous crops: includes cultivated herbaceous plants (graminoids or herbaceous plants) and crops used for hay. } \\
\text { All the non-perennial crops that do not last for more than two growing seasons and crops like sugar cane where the } \\
\text { upper part of the plant is regularly harvested while the root system can remain for more than one year in the field are } \\
\text { included. }\end{array}$ \\
\hline & $\begin{array}{l}\text { Woody crops: includes permanent crops (trees and/or shrub crops) and includes all types of orchards and plantations } \\
\text { (fruit trees, coffee and tea plantation, oil palm, rubber plantation, Christmas trees etc.). }\end{array}$ \\
\hline & $\begin{array}{l}\text { Multiple or layered crops: includes different land cover situations: } \\
\text { - Two layers of different crops (woody + herbaceous): A common case is the presence of woody crops (trees or shrubs) } \\
\text { and herbaceous crops, such as, wheat fields with olive trees in the Mediterranean area and intense horticulture, oasis } \\
\text { or typical coastal African agriculture where the cover for herbaceous fields is provided by palm trees, etc. } \\
\text { - Presence of one important layer of natural vegetation (mainly trees) that cover one layer of cultivated crops: a typical } \\
\text { example are coffee plantations shadowed by natural trees in the equatorial area of Africa. }\end{array}$ \\
\hline Grassland & $\begin{array}{l}\text { Includes any geographic area dominated by natural herbaceous plants (grasslands, prairies, steppes, and savannahs) } \\
\text { with a cover of } 10 \% \text { or more, irrespective of different human and/or animal activities, such as: grazing, selective fire } \\
\text { management etc. Woody plants (trees and/or shrubs) can be present providing their cover is less than } 10 \% \text {. }\end{array}$ \\
\hline Tree covered areas & $\begin{array}{l}\text { Includes any geographic area dominated by trees with a cover of } 10 \% \text { or more. Other types of plants (shrubs and/or } \\
\text { herbaceous) can be present, even at a density greater than the trees. Areas planted with trees for afforestation purpos- } \\
\text { es and forest plantations are included in this category, which also includes areas seasonally or permanently flooded } \\
\text { with fresh water, but not coastal mangroves. }\end{array}$ \\
\hline $\begin{array}{l}\text { Shrubs covered } \\
\text { areas }\end{array}$ & $\begin{array}{l}\text { Includes any geographic area dominated by shrubs with a cover of } 10 \% \text { or more. Other types of plants (herbaceous) } \\
\text { can be present, even at a density greater than shrubs. }\end{array}$ \\
\hline $\begin{array}{l}\text { Herbaceous } \\
\text { vegetation, aquatic } \\
\text { or regularly flooded }\end{array}$ & $\begin{array}{l}\text { Includes any geographic area dominated by natural herbaceous vegetation (cover of } 10 \% \text { or more) that is permanently } \\
\text { or regularly flooded by fresh or brackish water (swamps, marsh areas etc.). Flooding must persist for at least } 2 \text { months } \\
\text { per year to be considered regular. Woody vegetation (trees and/or shrubs) can be present if their cover is less than } \\
10 \% \text {. }\end{array}$ \\
\hline Mangroves & $\begin{array}{l}\text { Includes any geographical area dominated by woody vegetation (trees or shrubs) with a cover of } 10 \% \text { or more that is } \\
\text { permanently or regularly flooded by salt and/or brackish water located in coastal areas or in river deltas. }\end{array}$ \\
\hline Sparse vegetation & $\begin{array}{l}\text { Includes any geographic areas where the cover of natural vegetation is between } 2 \% \text { and } 10 \% \text {. This includes perma- } \\
\text { nently or regularly flooded areas. }\end{array}$ \\
\hline Bare soil & $\begin{array}{l}\text { Includes any geographic area dominated by natural abiotic surfaces (bare soil, sand, rocks, etc.) where the natural veg- } \\
\text { etation is absent or almost absent (covers less than } 2 \% \text { ) and areas regularly flooded by inland water (lake shores, river } \\
\text { banks, salt flats etc.), but not coastal areas affected by the tidal movement of salt water. }\end{array}$ \\
\hline Snow, glaciers & Includes any geographic area covered by snow or glaciers persistently for 10 months or more. \\
\hline Waterbodies & $\begin{array}{l}\text { Includes any geographic area covered for most of the year by inland water bodies. In some cases the water can be fro- } \\
\text { zen for part of the year (less than } 10 \text { months). Because the geographic extent of water bodies can change, boundaries } \\
\text { must be consistent with class } 11 \text { according to the dominant situation during a year and/or many years. }\end{array}$ \\
\hline
\end{tabular}



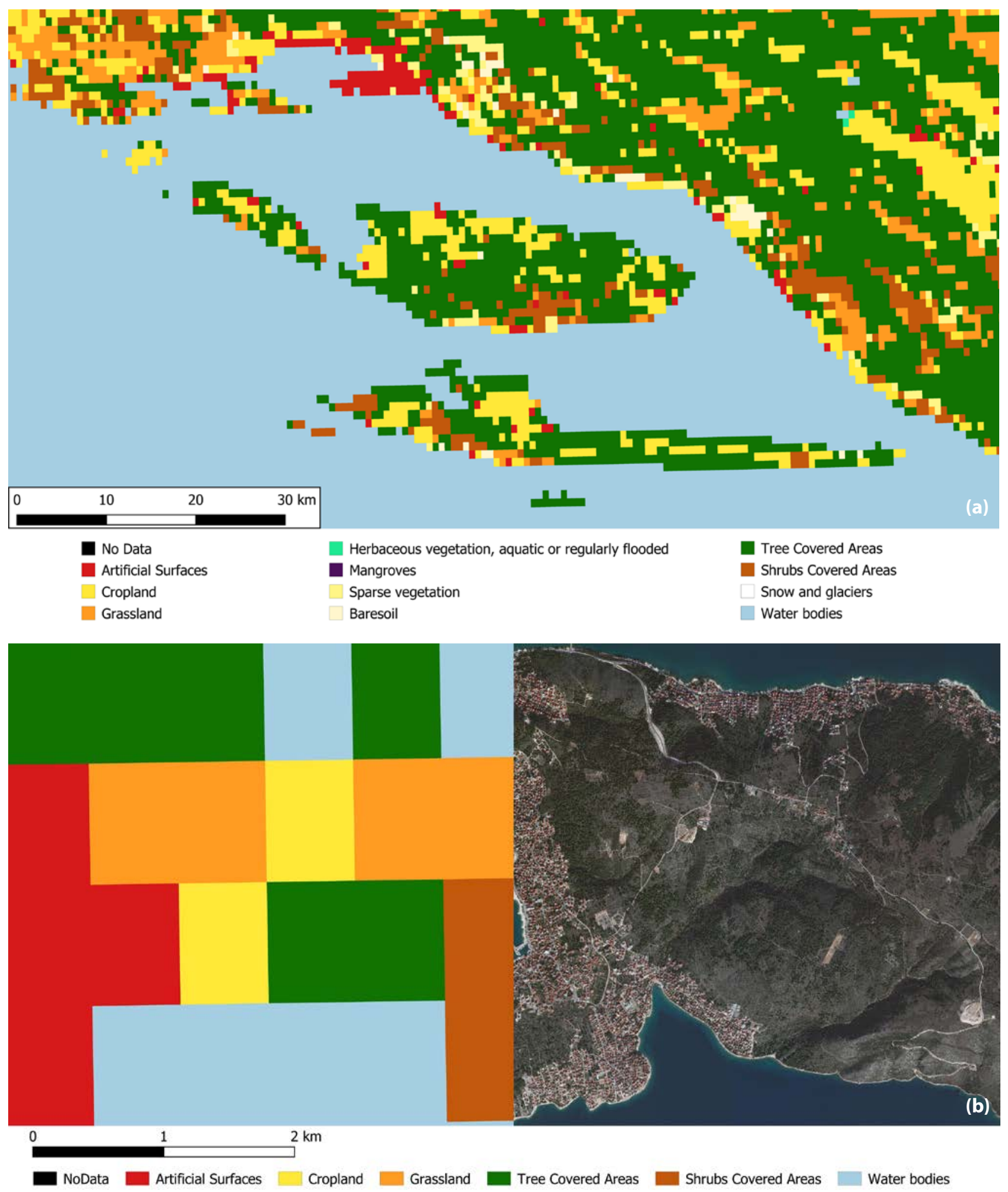

Fig. 3 Land cover map GLC-SHARE, (a) less detailed, legend includes all map classes; (b) more detailed, only map classes present in the area.

cludes a detailed description of each class (Table 4). This map not only doesn't accurately capture landscape features because of its resolution and number of classes, but it also omits several important details: distribution of urban areas, smaller islands, shape of coast line and so on (Fig. 3). Such resolution is hardly suitable for modelling species habitats.

\section{European Space Agency: GlobCover (Arino et al. 2012)}

Classification of GlobCover (Table 5) is compatible with the LCCS system. Fig. 4a shows that the map of this region does not truly represent urban areas (there should be more red colour along the coast, as in Fig. $2 \mathrm{a}$, at a similar resolution). Fig. $4 \mathrm{~b}$ reveals another misclassification: forest was not identified. 
Table 5 Land cover classes of GLOBCOVER map, adapted from Arino et al. (2012).

\begin{tabular}{|c|c|}
\hline Land cover classes & Land cover classes \\
\hline Post-flooding or irrigated cropland (or aquatic) & $\begin{array}{l}\text { Closed to open ( }>15 \%) \text { (broadleaved or coniferous, evergreen } \\
\text { or deciduous) shrubland }(<5 \mathrm{~m})\end{array}$ \\
\hline Rainfed cropland & $\begin{array}{l}\text { Closed to open (> 15\%) herbaceous vegetation (grassland, } \\
\text { savannas or lichens/mosses) }\end{array}$ \\
\hline $\begin{array}{l}\text { Mosaic cropland (50-70\%) / vegetation (grassland/shrubland/forest) } \\
(20-50 \%)\end{array}$ & Sparse $(<15 \%)$ vegetation \\
\hline $\begin{array}{l}\text { Mosaic vegetation (grassland/shrubland/forest) }(50-70 \%) \text { / cropland } \\
(20-50 \%)\end{array}$ & $\begin{array}{l}\text { Closed to open ( }>15 \% \text { ) broadleaved forest regularly flooded } \\
\text { (semi-permanently or temporarily) - Fresh or brackish water }\end{array}$ \\
\hline $\begin{array}{l}\text { Closed to open (> 15\%) broadleaved evergreen or semi-deciduous } \\
\text { forest }(>5 \mathrm{~m})\end{array}$ & $\begin{array}{l}\text { Closed ( }>40 \% \text { ) broadleaved forest or shrubland permanently } \\
\text { flooded - Saline or brackish water }\end{array}$ \\
\hline Closed (> 40\%) broadleaved deciduous forest ( $>5 \mathrm{~m}$ ) & $\begin{array}{l}\text { Closed to open (>15\%) grassland or woody vegetation on regularly } \\
\text { flooded or waterlogged soil - Fresh, brackish or saline water }\end{array}$ \\
\hline Open (15-40\%) broadleaved deciduous forest/woodland (>5 m) & Artificial surfaces and associated areas (Urban areas > 50\%) \\
\hline Closed $(>40 \%)$ coniferous evergreen forest $(>5 \mathrm{~m})$ & Bare areas \\
\hline Open (15-40\%) coniferous deciduous or evergreen forest $(>5 \mathrm{~m})$ & Water bodies \\
\hline Closed to open ( $>15 \%)$ mixed broadleaved and coniferous forest $(>5 \mathrm{~m})$ & Permanent snow and ice \\
\hline Mosaic forest or shrubland (50-70\%) / grassland (20-50\%) & No data (burnt areas, clouds...) \\
\hline Mosaic grassland (50-70\%) / forest or shrubland (20-50\%) & \\
\hline
\end{tabular}

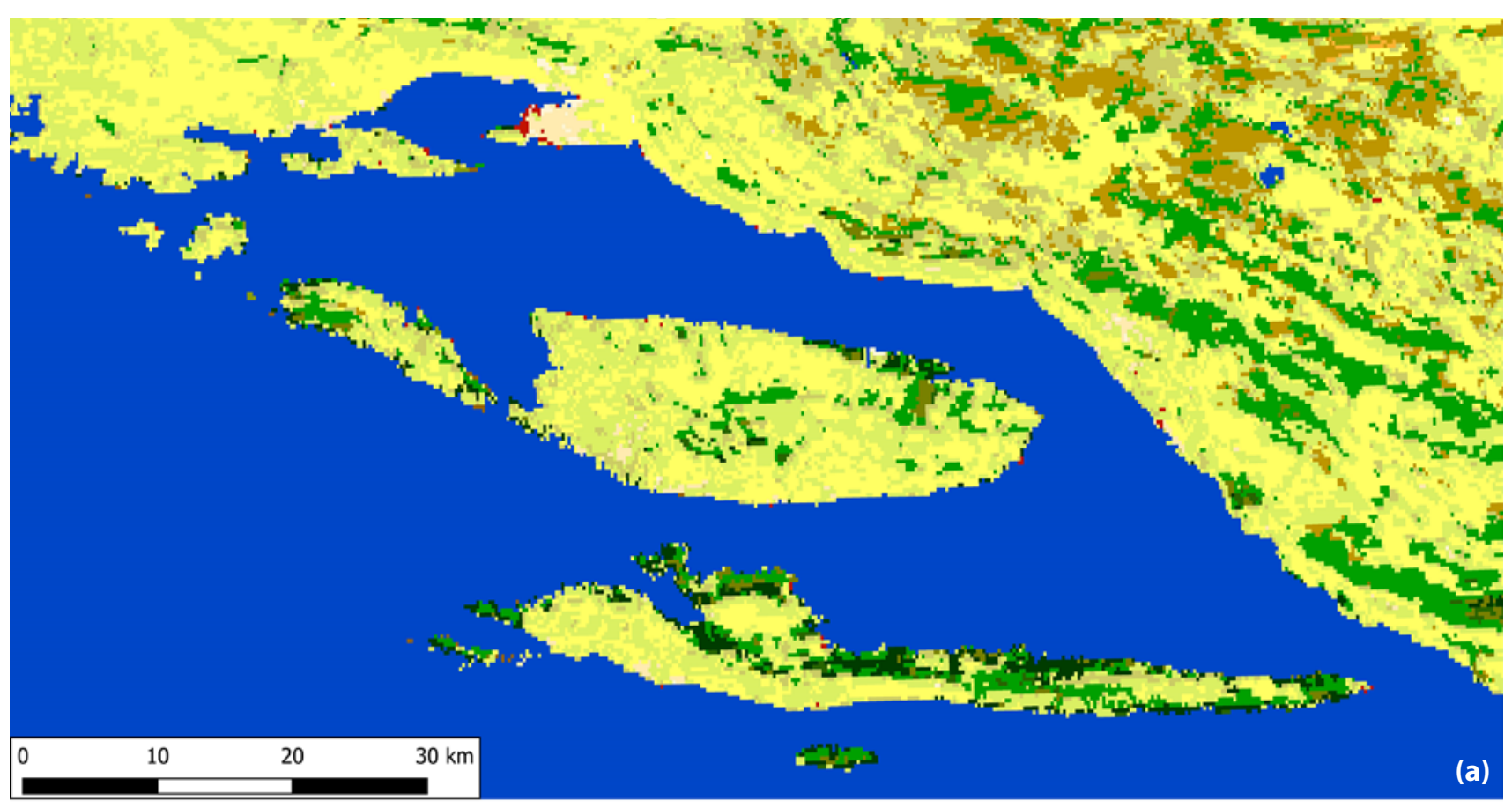

Post-flooding or irrigated croplands (or aquatic)

Rainfed croplands

Mosaic cropland (50-70\%) / vegetation (grassland/shrubland/forest) (20-50\%)

Mosaic vegetation (grassland/shrubland/forest) (50-70\%) / cropland (20-50\%)

- Closed to open ( $>15 \%$ ) broadleaved evergreen or semi-deciduous forest $(>5 \mathrm{~m}$ )

Closed $(>40 \%)$ broadleaved deciduous forest $(>5 \mathrm{~m})$

Open (15-40\%) broadleaved deciduous forest/woodland $(>5 \mathrm{~m})$

- Closed (>40\%) needleleaved evergreen forest ( $>5 \mathrm{~m}$ )

- Open (15-40\%) needleleaved deciduous or evergreen forest (>5m)

Closed to open ( $>15 \%$ ) mixed broadleaved and needleleaved forest $(>5 \mathrm{~m})$

Mosaic forest or shrubland (50-70\%) / grassland (20-50\%)

Mosaic grassland $(50-70 \%) /$ forest or shrubland $(20-50 \%)$

Closed to open ( $>15 \%)$ shrubland $(<5 \mathrm{~m})$

(broadleaved or needleleaved, evergreen or deciduous)
- Closed to open (>15\%) herbaceous vegetation (grassland, savannas or lichens/mosses)

Sparse $(<15 \%)$ vegetation

Closed to open ( $>15 \%$ ) broadleaved forest regularly flooded (semi-permanently or temporarily) - Fresh or brackish water

Closed ( $>40 \%$ ) broadleaved forest or shrubland permanently flooded Saline or brackish water

- Closed to open (>15\%) grassland or woody vegetation on regularly flooded or waterlogged soil - Fresh, brackish or saline water

- Artificial surfaces and associated areas (Urban areas $>50 \%$ ) Bare areas

Water bodies

Permanent snow and ice

- No data (burnt areas, clouds,...)

European Journal of Environmental Sciences, Vol. 11, №. 1 


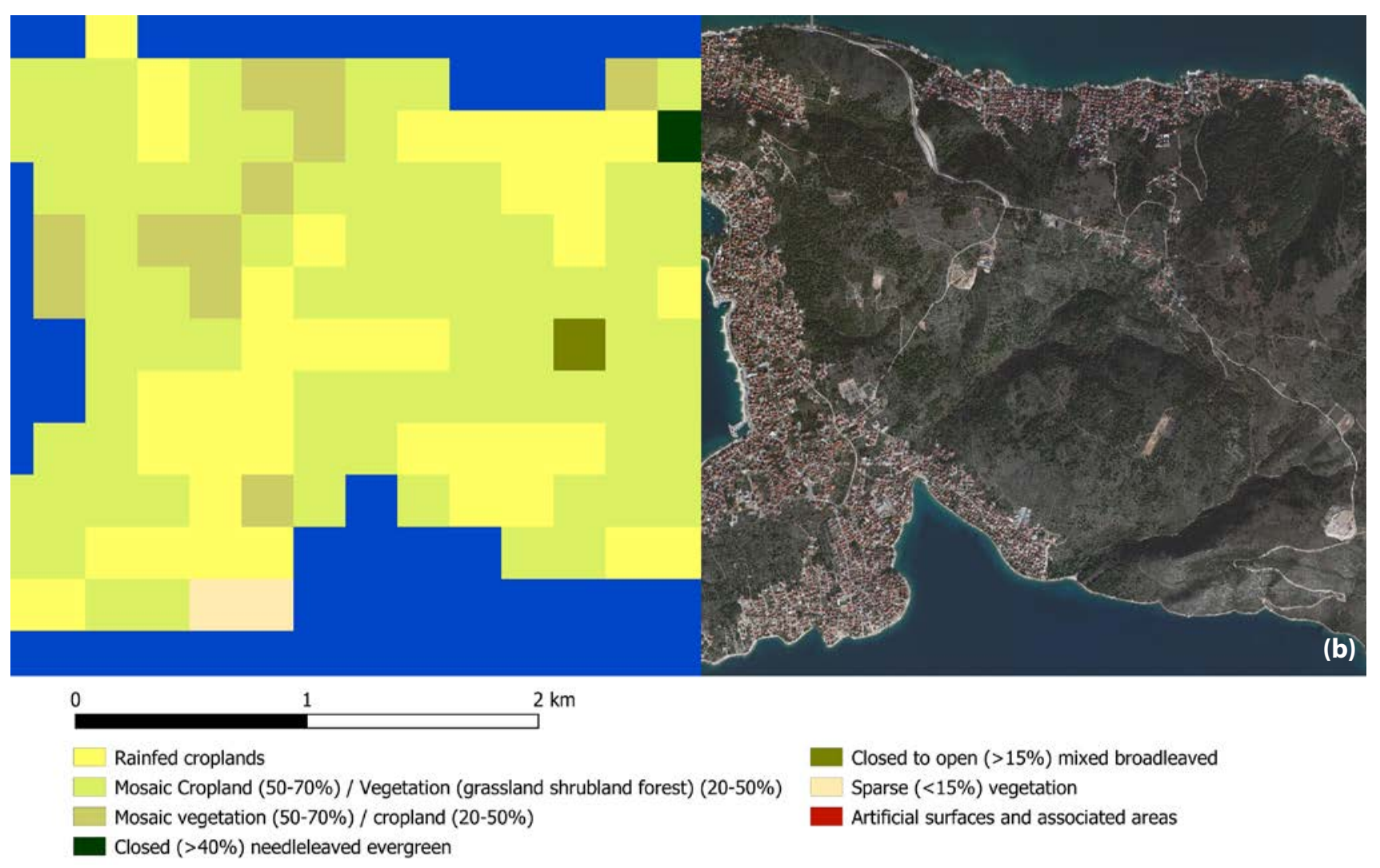

Fig. 4 Land cover map GlobCover: (a) less detailed, legend includes all map classes; (b) more detailed, only map classes present in the area.

\section{GLC_FCS30 map, open access (Liangyun et al. 2020)}

This map has 24 classes (Table 6), but is not compatible with the LCCS classification system. There are some misclassifications in this map along the coastline, but because of its resolution, it captures the finer details (Fig. 5). It also has some minor artefacts, such as: "orchards" along roads; small patches of "shrubland" within "closed forest", despite the fact that in the various satellite images forest appears to be homogeneous at such locations; occasionally roads are classified as "herbaceous cover". These minor misclassifications are correctable. However, this map has a more serious problem. Since sections of these maps overlap (Fig. 6a) and classification in the overlapping sections differs (Fig. 6b), these maps must be processed before they can be used for analysis. In contrast, the Copernicus (CGLS-LC100 map) map does not have such a

Table 6 Land cover classes GLC_FCS30 map, adapted from Liangyun et al. (2020). Classes with (*) are not present in map legend, these classes were added to categorize the legend.

\begin{tabular}{|c|c|c|c|}
\hline \multicolumn{2}{|c|}{ Land cover classes } & \multicolumn{2}{|l|}{ Land cover classes } \\
\hline \multirow{3}{*}{$\begin{array}{l}\text { Cropland } \\
\text { classes* }\end{array}$} & Rainfed cropland & \multirow{2}{*}{ Shrubland } & Evergreen shrubland \\
\hline & Orchard & & Deciduous shrubland \\
\hline & Irrigated cropland & Herbaceous cover & \\
\hline \multirow{4}{*}{$\begin{array}{l}\text { Evergreen } \\
\text { forest types* }\end{array}$} & Open evergreen broadleaved forest & Tree or shrub cover & \\
\hline & Open evergreen broadleaved forest & Grassland & \\
\hline & Open evergreen needle-leaved forest & \multirow{2}{*}{ Sparse vegetation } & Sparse shrubland \\
\hline & Closed evergreen needle-leaved forest & & Sparse herbaceous vegetation \\
\hline \multirow{4}{*}{$\begin{array}{l}\text { Deciduous } \\
\text { forest types* }\end{array}$} & Open deciduous broadleaved forest & Lichens and mosses & \\
\hline & Closed deciduous broadleaved forest & Wetlands & \\
\hline & Closed deciduous needle-leaved forest & Impervious surfaces & \\
\hline & Open deciduous needle-leaved forest & \multirow{2}{*}{ Bare areas } & Unconsolidated bare areas \\
\hline \multirow{2}{*}{$\begin{array}{l}\text { Mixed leaf } \\
\text { forest types* }\end{array}$} & Open mixed broadleaved and needle-leaved forest & & Consolidated bare areas \\
\hline & Closed mixed broadleaved and needle-leaved forest & Water body & \\
\hline & & Permanent ice and snow & \\
\hline
\end{tabular}




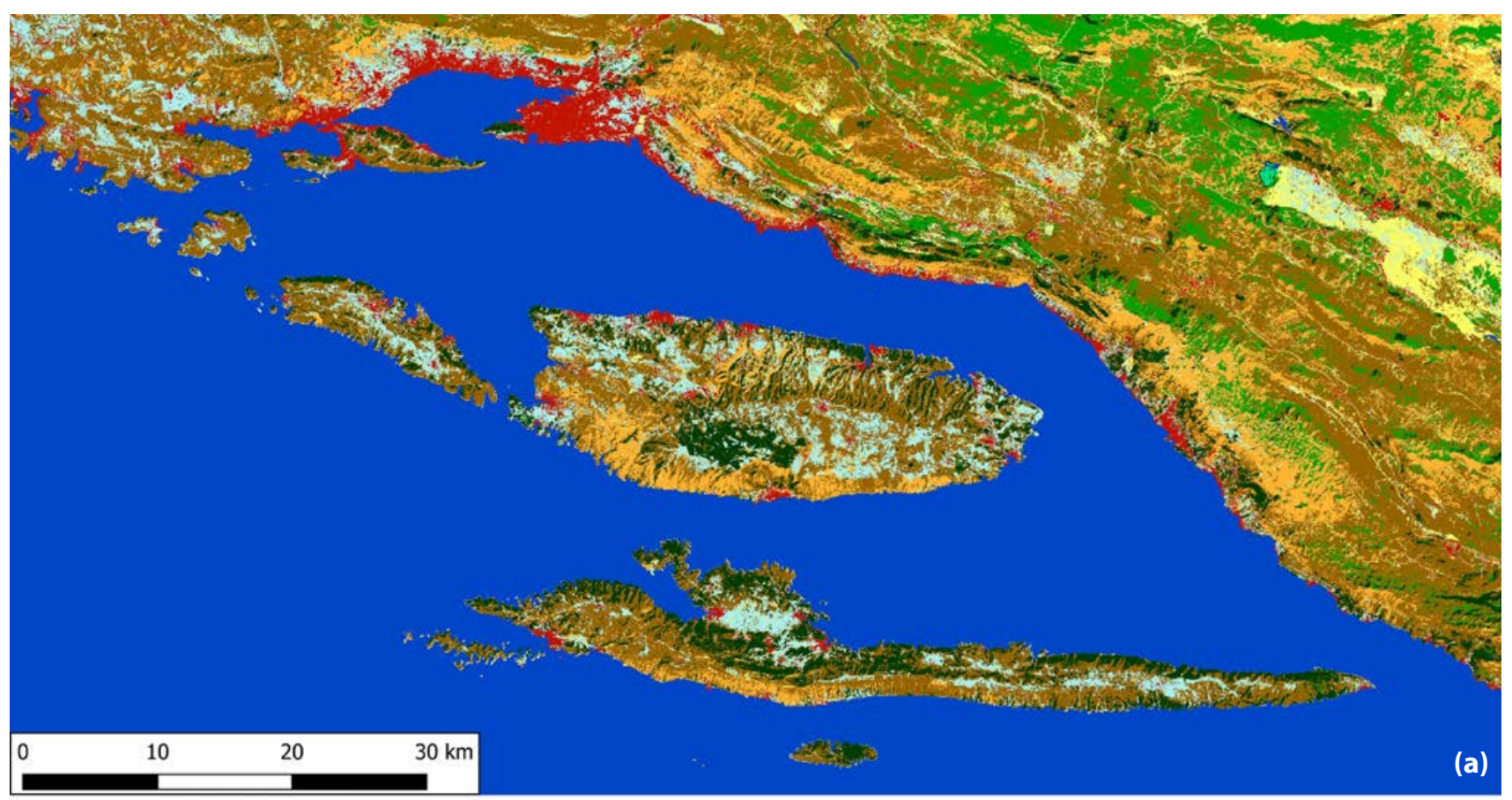

\begin{tabular}{|c|c|c|}
\hline 0 & Open evergreen needle-leaved forest $(0.15<\mathrm{fc}<0.4)$ & Wetlands \\
\hline Rainfed cropland & Closed evergreen needle-leaved forest ( $\mathrm{fc}>0.4$ ) & Impervious surfaces \\
\hline Herbaceous cover & Open mixed leaf forest (broadleaved and needle-leaved) & Bare areas \\
\hline Tree or shrub cover (Orchard) & Closed mixed leaf forest (broadleaved and needle-leaved) & Water body \\
\hline Irrigated cropland & Shrubland & Permanent ice and snow \\
\hline Open deciduous broadleaved forest $(0.15<\mathrm{fc}<0.4)$ & Grassland & \\
\hline Closed deciduous broadleaved forest ( $\mathrm{fc}>0.4$ ) & Sparse vegetation $(\mathrm{fc}<0.15)$ & \\
\hline
\end{tabular}

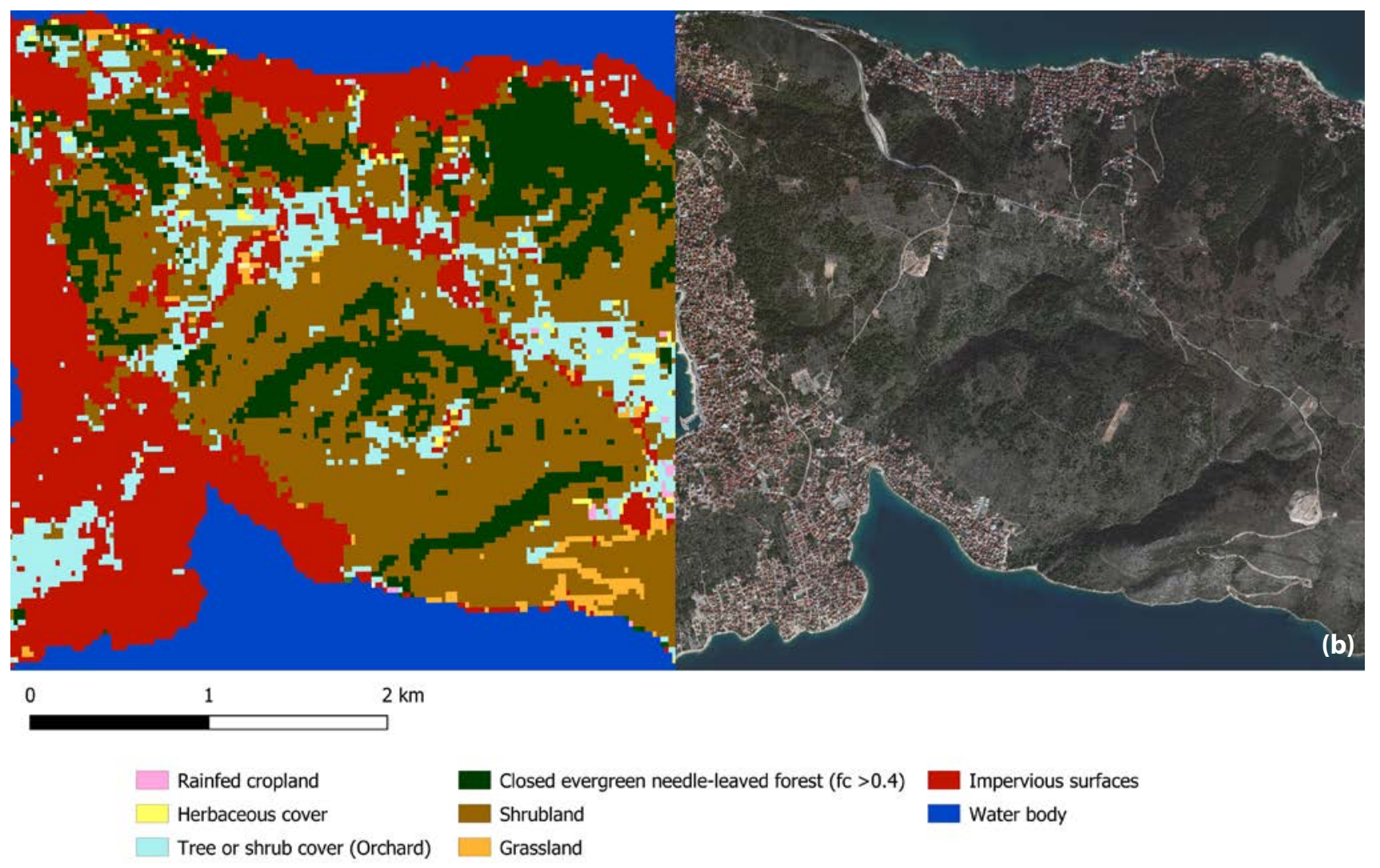

Fig. 5 Land cover map GLC_FCS30, (a) less detailed, legend includes all map classes; (b) more detailed, only includes classes present in the area. 

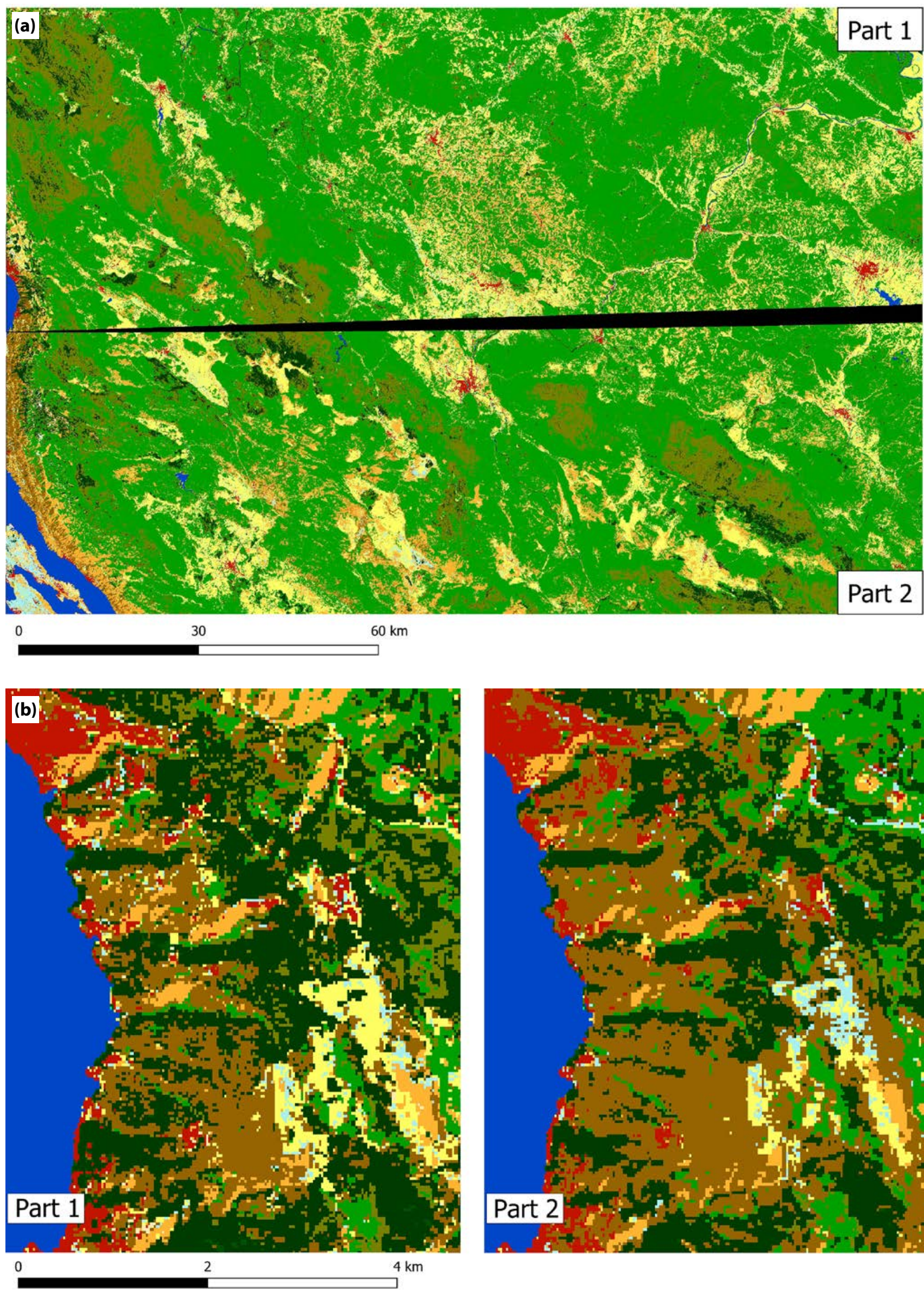

Part 2

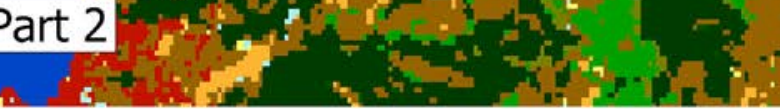

Fig. 6 Land cover map GLC_FCS30, (a) alignment between part 1 (E15N50) and part 2 (E15N45), extent of the area: 45.38, 14.9; 44.48, 16.82; (b) differences between overlapping sections, and the extent of the area: $44.98,14.91,44.93,14.98$. Parts' codes are section designations of GLC FCS30. 


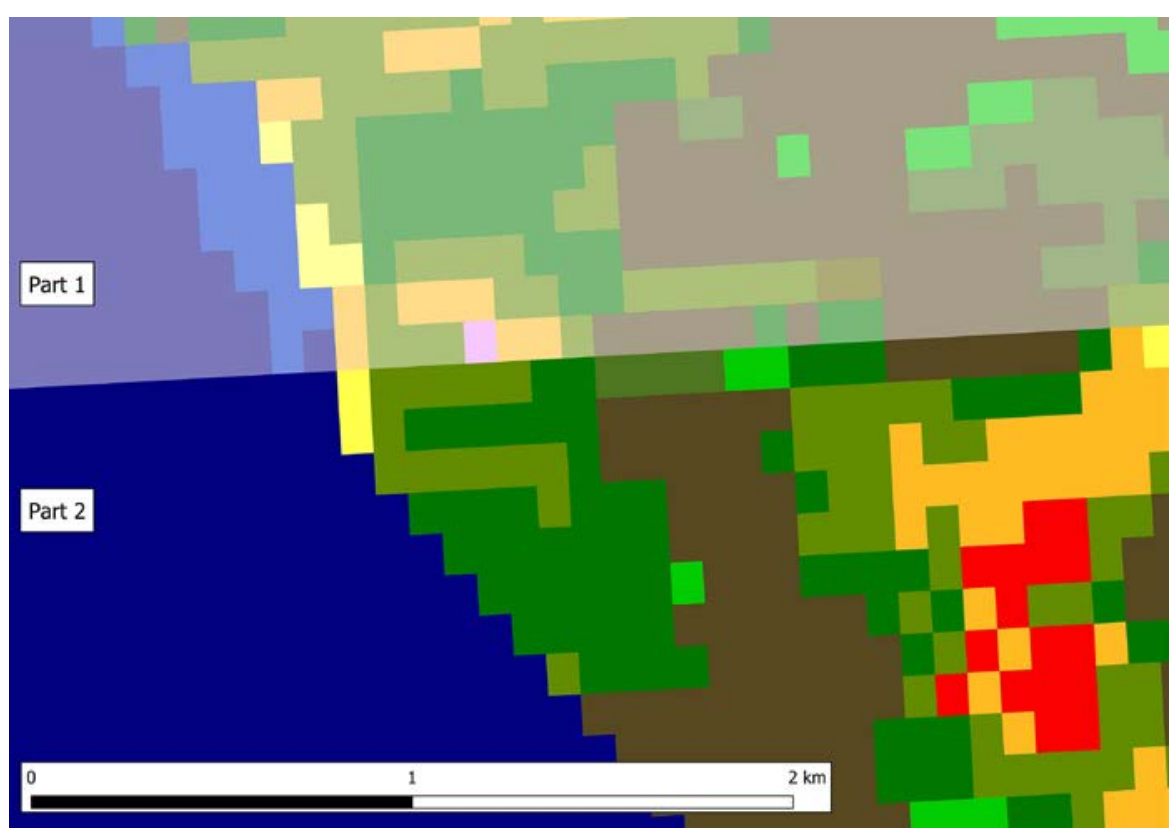

Fig. 7 CGLS-LC100 map's section alignment.

problem (Fig. 7), despite the fact that this map was also downloaded in the same way, by individual sections. On such a small scale $(30 \mathrm{~m})$, these differences are significant and will affect the results of the analysis.

\section{FROM-GLC10 map (Gong et al. 2019)}

This map is the first freely available global land cover map with a resolution of $10 \mathrm{~m}$. Map for 2015 has regional level classification, map for 2017 only global classification (Table 7). This map's sections are well aligned, with only one pixel separating them. The colouring of the FROMGLC10 map is the same as that of the ESA CCI-LC map and some regional level groups have the same colour as the global level class (Fig. 8a), making it difficult to estimate the level of detail of this map online. In this particular area this map tends to classify sparse herbaceous vegetation or shrubland as "Natural grassland". As there is no explanation of classification parameters or comparison with the LCCS system, it is difficult to determine whether this map classifies this type of vegetation correctly.

\section{Conclusions}

At a global scale, study maps should be compared for several parts of the main target area of a study. For correct comparison, these maps should be downloaded and then carefully investigated. Some maps may provide a better representation of particular classes than others. Note that the ideal classification of a large number of classes at a small resolution is almost unachievable, but such minor misclassifications can be easily fixed.

During this investigation it was observed that for the particular area studied, most maps appear to misclassify sparse mosaic shrub and herbaceous vegetation (prob-
Table 7 Regional and global classification for the FROM-GLC10 map, adapted from Gong et al. (2019).

\begin{tabular}{|c|c|}
\hline \multicolumn{2}{|l|}{ Map land cover class } \\
\hline Global level classification & Regional level classification \\
\hline \multirow{5}{*}{ Cropland } & Rice paddy \\
\hline & Greenhouse \\
\hline & Orchard \\
\hline & Bare farmland \\
\hline & Other \\
\hline \multirow{6}{*}{ Forest } & Broadleaved-on \\
\hline & Broadleaved-off \\
\hline & Needles-on \\
\hline & Needles-off \\
\hline & Mixed leaved-on \\
\hline & Mixed leaved-off \\
\hline \multirow{3}{*}{ Grassland } & Natural grassland \\
\hline & Desiccated \\
\hline & Pasture \\
\hline \multirow{2}{*}{ Shrubland } & Shrubland, leaves-on \\
\hline & Shrubland, leaves-off \\
\hline \multirow{3}{*}{ Wetland } & Marshland \\
\hline & Marshland, leaves-off \\
\hline & Mudflat \\
\hline \multirow{2}{*}{ Tundra } & Shrub and brush tundra \\
\hline & Herbaceous tundra \\
\hline \multirow{2}{*}{ Snow/lce } & Snow \\
\hline & Ice \\
\hline \multicolumn{2}{|l|}{ Water } \\
\hline \multicolumn{2}{|l|}{ Impervious surface } \\
\hline \multicolumn{2}{|l|}{ Bare land } \\
\hline Cloud & \\
\hline
\end{tabular}



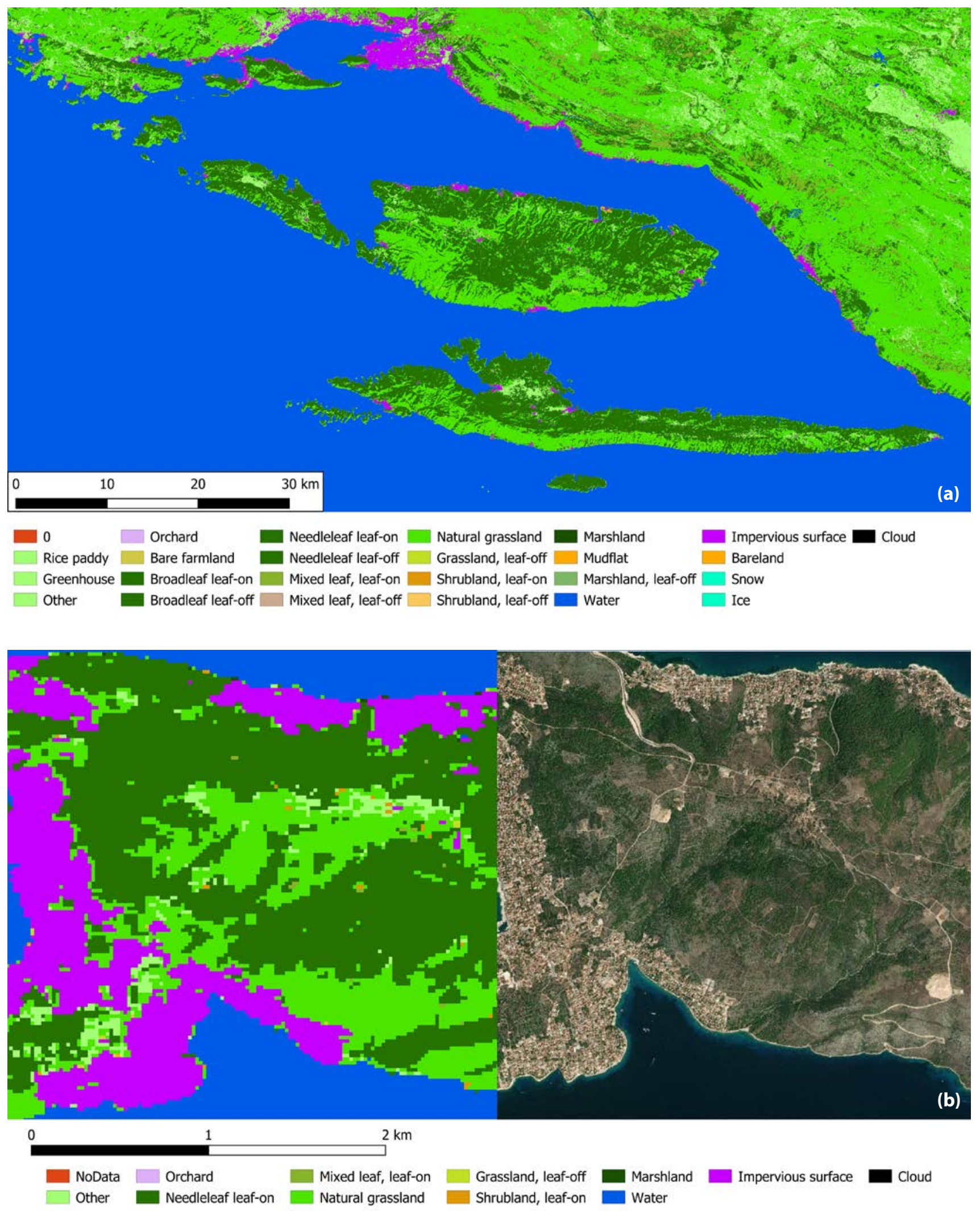

Fig. 8 FROM-GLC10 map, (a) less detailed, legend includes all map classes; (b) more detailed, only those classes present in area are shown.

ably perennial) mixed with bare soil (rocks), visible on satellite imagery. The Copernicus CGLS-LC map tends to indicate that this area is covered by crops or cultivated and managed vegetation, despite the fact that it has more suitable classes. The ESA CCI-LC map, on the other hand, classifies these areas as "Cropland rainfed", which is mostly correct; or incorrect as "Tree cover broadleaved deciduous closed to open (> 15\%)". However, this could be a problem unique to this area that requires further investigation. The GLOBCOVER map provides a mislead- 
ing classification of particular types of vegetation (forest) and incorrect classification of urban areas, which make this map unsuitable for use for studying this area. The resolution of map GLC-SHARE from FAO is too coarse for evaluating habitat suitability as it does not describe the pattern of vegetation or even the shape of the mainland. There may be another version of the GLC_FCS30 map (Liangyun et al. 2020) that is properly aligned and has averaged classification for overlapping parts, which is more accurate. FROM-GLC10 map (Gong et al. 2019) is the first global map that is freely available with such small resolution. This map has some noticeable artefacts due to its resolution, $10 \mathrm{~m}$, however, such minor artefacts can be removed. ESA CCI-LC and Copernicus CGLSLC100 maps provide the most accurate estimates for the area studied. Incorrect position of classes CCI-LC map against satellite imagery (Gorelick et al. 2017) may be due to the level of resolution. Both maps sometimes misclassify certain types of vegetation (sparse vegetation on bare soil), but if this is consistent and exclusive to this region, it can be manually corrected.

This comparison indicates that the Copernicus CGLSLC100 and ESA CCI-LC maps seem to be the most universal maps for determining potentially suitable habitats. They have a wide range of land cover groups that can be compared (using LCCS classification system), making it easier to decide which spatial resolution to use.

\section{REFERENCES}

Arino O, Ramos Perez JJ, Kalogirou V, Bontemps S, Defourny P, van Bogaert E (2012) Global Land Cover Map for 2009 (GlobCover 2009). European Space Agency and Université catholique de Louvain. doi: 10.1594/PANGAEA.787668.

Barik S, Saha GK, Mazumdar S (2021) Potentially suitable habitat, connectivity and priority conservation areas for White-breasted waterhen (Amaurornis phoenicurus) and Bronze-winged jacana (Metopidius indicus). Wetl 41. doi: 10.1007/s13157-02101433-6.

Breininger DR, Toland B, Oddy DM, Legare ML (2006) Landcover characterizations and Florida scrub-jay (Aphelocoma coerulescens) population dynamics. Biol Conserv 128: 169-181.

Buchhorn M, Smets B, Bertels L, Roo BD, Lesiv M, Tsendbazar NE, Herold M, Fritz S (2020) Copernicus Global Land Service: Land Cover 100m: collection 3: epoch 2015: Globe. doi: org/10.5281/ZENODO.3939038.

Buchhorn M, Smets B, Bertels L, Roo BD, Lesiv M, Tsendbazar NE, Li L, Tarko A (2021) Copernicus Global Land Service: Land Cover 100 m: version 3 Globe 2015-2019: Product User Manual. doi: 10.5281/ZENODO.4723921.

Cisneros-Araujo P, Goicolea T, Mateo-Sánchez MC, García-Viñás JI, Marchamalo M, Mercier A, Gastón A (2021) The Role of Remote Sensing Data in Habitat Suitability and Connectivity Modeling: Insights from the Cantabrian Brown Bear. Remote Sens 13: 1138.

Ciudad C, Mateo-Sánchez MC, Gastón A, Blazquez-Cabrera S, Saura S (2021) Landscape connectivity estimates are affected by spatial resolution, habitat seasonality and population trends. Biodivers and Conserv 30: 1395-1413.
ESA (2017) Land Cover CCI Product User Guide Version 2. Tech Rep. Available at: maps.elie.ucl.ac.be/CCI/viewer/download /ESACCI-LC-Ph2-PUGv2_2.0.pdf.

Falcucci A, Maiorano L, Boitani L (2007) Changes in land-use/ land-cover patterns in Italy and their implications for biodiversity conservation. Landscape Ecol 22: 617-631.

GLCC Global Land Cover Characterization. United States Geological Survey Land Cover Products: doi: 10.5066/F7GB230D.

Goldewijk KK, Hall FG, Collatz GJ, Meeson BW, Los SO, Brown De Colstoun E, Landis DR (2007) ISLSCP II Historical Land Cover and Land Use, 1700-1990. ORNL DAAC, Oak Ridge, Tennessee, USA. doi: 10.3334/ORNLDAAC/967.

Gong P, Liu H, Zhang M et al. (2019) Stable classification with limited sample: transferring a 30-m resolution sample set collected in 2015 to mapping 10-m resolution global land cover in 2017. Sci Bull 64: 370-373.

Gorelick N, Hancher M, Dixon M, Ilyushchenko S, Thau D, Moore R (2017) Google Earth Engine: Planetary-scale geospatial analysis for everyone. Remote Sens of Environ 202: 18-27.

Hirzel AH, le Lay G (2008) Habitat suitability modelling and niche theory. J Appl Ecol 45: 1372-1381.

Latham J, Cumani R, Rosati I, Bloise M (2014) FAO Global Land Cover (GLC-SHARE). Beta-Release 1.0 Database. http://www .fao.org/geonetwork/srv/en/main.home?uuid=ba4526fd-cdbf -4028 -a1bd-5a559c4bff38.

Li X, Ling F, Foody GM, Ge Y, Zhang Y, Du Y (2017) Generating a series of fine spatial and temporal resolution land cover maps by fusing coarse spatial resolution remotely sensed images and fine spatial resolution land cover maps. Remote Sens of Environ 196: 293-311.

Liangyun L, Xiao Z, Xidong C, Yuan G, Jun M (2020) GLC_FCS30: Global land-cover product with fine classification system at 30 $\mathrm{m}$ using time-series Landsat imagery. doi: 10.5281/ZENODO.3986872.

Manton MG, Angelstam P, Mikusiński G (2005) Modelling habitat suitability for deciduous forest focal species - A sensitivity analysis using different satellite land cover data. Landscape Ecol 20: $827-839$.

MAXAR (2021) Basevue LULC, Remote Sensing. https://www .maxar.com/products/basevue-lulc.

McMenamin SK, Hadly EA, Wright CK (2008) Climatic change and wetland desiccation cause amphibian decline in Yellowstone National Park. Proc Natl Acad Sci U.S.A. 105: 16988-16993.

Ndegwa Mundia C, Murayama Y (2009) Analysis of Land Use/ Cover Changes and Animal Population Dynamics in a Wildlife Sanctuary in East Africa. Remote Sens 1: 952-970.

Novillo C, Arrogante-Funes P, Romero-Calcerrada R (2018) Improving Land Cover Classifications with Multiangular Data: MISR Data in Mainland Spain. Remote Sens 10: 1717.

Pennington DN, Hansel J, Blair RB (2008) The conservation value of urban riparian areas for landbirds during spring migration: Land cover, scale, and vegetation effects. Biol Conserv 141: 1235-1248.

Rawat JS, Kumar M (2015) Monitoring land use/cover change using remote sensing and GIS techniques: A case study of Hawalbagh block, district Almora, Uttarakhand, India. Egypt J Remote Sens Space Sci 18: 77-84.

Rondinini C, di Marco M, Chiozza F et al. (2011) Global habitat suitability models of terrestrial mammals. Philos T Roy Soc B 366: 2633-2641.

Teng J, Xia S, Liu Y, Yu X, Duan H, Xiao H, Zhao C (2021) Assessing habitat suitability for wintering geese by using Normalized Difference Water Index (NDWI) in a large floodplain wetland, China. Ecol Indic 122: 107260. 


\section{LINKS TO THE MAPS}

1. Copernicus, CGLS- LC100 map (Buchhorn et al. 2020): https:// land.copernicus.eu/global/products/lc

2. Food and Agriculture Organization of the United Nations (FAO), GLC-SHARE map (Latham et al. 2014): http://www .fao.org/geonetwork/srv/en/main.home?uuid=ba4526fd-cdbf -4028-a1bd-5a559c4bff38
3. European Space Agency (ESA), CCI-LC map (ESA 2017): http:// www.esa-landcover-cci.org/?q=node/164

4. European Space Agency (ESA), GLOBCOVER map (Arino et al. 2012): http://due.esrin.esa.int/page_globcover.php

5. Liangyun et al. 2020, GLC_FCS30 map: https://zenodo.org /record/4280923\#.YIzydbUzY2w

6. Gong et al. 2019, FROM-GLC10 map: http://data.ess.tsinghua .edu.cn/fromglc10_2017v01.html 